\title{
Editorial
}

\section{Reform the WTO to Advance Services Trade Liberalization}

It is highly regrettable that instead of building on the General Agreement on Trade in Services (GATS) adopted in the Uruguay Round, the World Trade Organization (WTO) is reported to have failed to even update or strengthen the GATS in the protracted Doha Round negotiations. The most frequent apologies for this are that the 153 WTO members are far more interested in agricultural and manufacturing issues than services. Further the present WTO structure is considered too limiting in requiring consensus on an entire sector if changes are to be achieved. Major economies are said to insist on sub-sector negotiations for a number of the 30 widely different service sectors.

A policy brief issued by the Carnegie Endowment for Peace, based in Washington, calls for "WTO reforms needed today." Specifically, it urges the WTO to adopt "a more flexible approach to trade negotiations, tailored to the needs of individual countries and groups. The institution should move beyond multilateral all-ornothing negotiations that are bearing little fruit and find ways to leverage opportunities where liberalization is taking place. A formal discussion about reform should get underway during the WTO's ministerial meeting in Geneva in November. The WTO has been the guardian of stability and predictability in world trade, but has failed to fulfill its promise as a source of new trade rules and liberalization."

Russell Pipe, Editor in Chief 